НАУКОВИЙ ВІСНИК

Sientific messenger of Lviv National University

axts

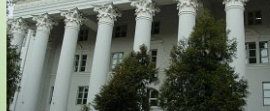

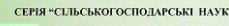

(3)) Tом 22 № 93

2020
Науковий вісник Дьвівського національного університету ветеринарної медицини та біотехнологій імені С.3. Гжицького. Серія: Сільськогосподарські науки

Scientific Messenger of Lviv National University of Veterinary Medicine and Biotechnologies. Series: Agricultural sciences

UDC 638.19:638.1:633.31

\title{
Manganese metabolism in the body of the honey bee (Apis mellifera L.) at different periods of ontogenesis
}

\author{
Y. Kovalskyi, L. Kovalska, P. Golovach, V. V. Fedak, A. I. Druzhbiak \\ Stepan Gzhytskyi National University of Veterinary Medicine and Biotechnologies Lviv, Ukraine
}

Article info

Received 26.08.2020

Received in revised form 28.09.2020

Accepted 29.09.2020

Stepan Gzhytskyi National University of Veterinary Medicine and Biotechnologies Lviv, Pekarska Str., 50, Lviv, 79010, Ukraine.

Tel.:+38-067-938-54-13 E-mail: prikarpatmed@ukr.net
Kovalskyi, Y., Kovalska, L., \& Golovach, P. (2020). Manganese metabolism in the body of the honey bee (Apis mellifera L.) at different periods of ontogenesis. Scientific Messenger of Lviv National University of Veterinary Medicine and Biotechnologies. Series: Agricultural sciences, 22(93), 7478. doi: 10.32718/nvlvet-a9313

The results of studies of manganese metabolism in honey bees are presented. The study was conducted in conditions of the department of technology of production and processing of small animals of Stepan Gzhytskyi National University of Veterinary Medicine and Biotechnologies Lvivy. In the course of work the material selected on an educational apiary of university was investigated and in some apiaries of Lviv region. In particular, samples of different species were taken for study pollen. The study was pollen, which was selected after 15 days of storage in the hive. Along with this, the material for the study was honey, royal jelly, wax. From the biological material we studied the mineral composition of larvae and bees stages of adults of different ages and genders. One-day-old worker bees and drones in May, August, and December were selected to determine seasonal change and sex differences. Research of age changes in larvae 3 and 6 days of age were carried out by sampling biological material from 5 bee families of equal strength and feeding regime. A frame was used to obtain a one-year-old brood-an insulator in which a cell with a uterus for laying eggs was placed. After the bees come out of the cells they were placed in one family. The main sources of its entry into the body have been studied. It is established that the largest amount of manganese is contained in samples of dandelion and winter oilseed rape and is $4.5 \mathrm{mg} / 100 \mathrm{~g}$ of pollen. The smallest amount of Manganese $1.87 \mathrm{mg} / 100$ was recorded in clover skin $\mathrm{g}$. The insignificant content of Manganese in bee pollen from buckwheat of $2.32 \mathrm{mg} / 100 \mathrm{~g}$. Manganese metabolism in the body of honey bees at different stages of ontogenesis has been studied. In particular, the chemical composition of muscle fibers of adult bees, larvae of different ages was studied. the content of this element in different departments of insects. The dynamics of manganese accumulation is observed not only depending on sex, age, season of the year, and also on physiological features of bee families. The content of Manganese in the main products of beekeeping: royal jelly, honey, wax and bee pollen. According to research, the main number Manganese in the body of honey bees is contained in the cuticle - the outer skeleton that covers it body and chitinous formations that make up the internal skeleton. Its amount averages $1.78 \mathrm{mg} / 100 \mathrm{~g}$. In the body of the bee, the manganese content varies widely.

Key words: honey bees, manganese, ontogenes, larvae, pollen, muscles, royal jelly.

\section{Метаболізм мангану в організмі медоносної бджоли (Apis mellifera L.) на різних періодах онтогенезу}

\author{
Ю. В. Ковальський, Л. М. Ковальська, П. І. Головач, В. В. Федак, А. Й. Дружбяк
}

Львівський національний університет ветеринарної медиџини та біотехнологій імені С. 3. Гжицького, м. Львів, Україна

Подані результати досліджень обміну Мангану у медоносних бджіл. Дослідження проводили в умовах кафедри технологї виробництва і переробки продукиї дрібних тварин ЛНУВМБ імені С. З. Гжицького. У процесі роботи досліджувався матеріал, відіб- 
раний на навчальній пасічі університету та на деяких пасіках Львівської області. Зокрема, для вивчення відбирались проби різних видів бджолиного обніжжя. Дослідженню підлягала перга, яка була відібрана після 15-добового зберігання у вулику. Поряд з цим, матеріалом для дослідження слугував мед золотарниковий, маточне молочко, віск. Із біологічного матеріалу нами досліджувався мінеральниц склад личинок та бджіл на стадї імаго різного віку і статі. Для визначення сезонної зміни та статевих відмінностей відбирали однодобових робочих бджіл і трутнів у травні, серпні та грудні. Дослідження вікових змін у личинок 3 та 6 добового віку проводили щляхом відбирання біологічного матеріалу із 5 бджолиних сімей однакової сили і режиму годівлі. Для одержання одновікового розплоду користувалися рамкою -ізолятором, в яку помішали стільник з маткою для відкладання яєць. Після виходу бджіл з комірок їх поміщали в одну сім'ю. Вивчено основні джерела його надходження в організм. Встановлено, ияо найбільша кількість Мангану міститься в зразках з кульбаби та ріпаку озимого і становить 4,5 мг/100 г обніжжя. У конюшиновому обніжжі зафіксована найменша кількість Мангану 1,87 мг/100 2. Звертає на себе увагу незначний вміст Мангану у бджолиному обніжжі з гречки 2,32 мг/100 г. Досліджено метаболізму Мангану в організмі медоносної бджоли на різних етапах онтогенезу. Зокрема, вивчено хімічний склад м'язових волокон дорослих бджіл, личинок різного віку. вміст иього елементу у різних відділах комах. Динаміка нагромадження Мангану спостерігається не тільки залежно від статі, віку, сезону року, а також і від фізіологічних особливостей бджолиних сімей. Досліджено вміст Мангану в основних продуктах бджільництва: маточному молочиі, меді, перзі, воску $i$ бджолиному обніжжі. Згідно проведених досліджень встановлено, щуо основна кількість Мангану в організмі медоносних бджіл міститься в кутикулі - зовнішньому скелеті, щзо покриває ї̈ тіло і хітинових утвореннях, щзо складають внутрішній скелет. Його кількість становить в середньому 1,78 мг/100 г.

Ключові слова: медоносні бджоли, Манган, онтогенез, личинки, перга, м'язи, маточне молочко.

\section{Ветуп}

Для вирощування 1 кг бджіл, сім'я витрачає у середньому 1,5 кг перги і 1,2 кг меду. Загалом за літній період вигодовується 150-200 тис. комах. Споживаючи при цьому таку кількість корму організм потребуе значних надходжень мінеральних речовин без яких неможливе безперервне протікання біохімічних процесів (Kovalskyi, 2005; Kerek et al., 2017). Серед метаболічних процесів важливим є обмін вуглеводів та ліпідів. Сприятливе протікання цього обміну великою мірою залежить від таких факторів годівлі, як наявність необхідних макро- і мікроелементів (Kovalskyi et al., 2018; Kovalchuk et al., 2019). Одним із важливих мікроелементів, що необхідний для нормального протікання фізіолого-біохімічних процесів в організмі бджіл є Манган. Надходження Мангану в організмі необхідне для утворення хітину і внутрішнього скелету медоносної бджоли. При цьому, Манган приймає участь у процесах репродуктивної функції. Входить до складу ферментних систем, які виконують окисновідновні реакції внутрішньоклітинного обміну. Він приймає участь у різних процесах метаболізму. Зокрема, від його наявності в організмі залежить інтенсивність синтезу есенціальних жирних кислот (Voronina et al., 2020). Однак, його обмін у медоносних бджіл вивчено недостатньо.

Все це свідчить про те, що питання вивчення мінерального складу пилку, меду та нагромадження мікроелементів i ix засвоєння організмом бджіл, пов'язане з вуглеводним обміном, що $є$ досить актуальним. Без вивчення цього питання не можливе теоретичне обгрунтування і практичне удосконалення технології живлення бджіл (Drujbiak et al., 2017).

Метою роботи було дослідження метаболізму Мангану в організмі медоносної бджоли на різних етапах онтогенезу.

\section{Матеріал і методи досліджень}

Дослідження проводили в умовах кафедри технології виробництва і переробки продукції дрібних тварин ЛНУВМБ імені С. З. Гжицького. У процесі роботи досліджувався матеріал, відібраний на навчальній пасіці університету та на деяких пасіках Львівської області. Зокрема, для вивчення відбирались проби різних видів бджолиного обніжжя. Дослідженню підлягала перга, яка була відібрана після 15-добового зберігання у вулику. Поряд з цим, матеріалом для дослідження слугував мед золотарниковий, маточне молочко, віск. Із біологічного матеріалу нами досліджувався мінеральниц склад личинок та бджіл на стадії імаго різного віку і статі.

Дані про структуру пилкових зерен отриманих методом їх ацетолізу, порівнювали з описами, які подані в довіднику Л. А. Куприянова і Л. А. Альошина (Kuprijanova \& Al'oshina, 1978). Для визначення сезонної зміни та статевих відмінностей відбирали однодобових робочих бджіл і трутнів у травні, серпні та грудні. Дослідження вікових змін у личинок 3 та 6добового віку проводили щляхом відбирання біологічного матеріалу із 5 бджолиних сімей однакової сили i режиму годівлі. Для одержання одновікового розплоду користувалися рамкою -ізолятором, в яку поміщали стільник з маткою для відкладання яєць. Після виходу бджіл з комірок їх поміщали в одну сім'ю.

Кількісний склад Мангану, визначали методом атомно-абсорбційної спекторофотометрії на приладі С115-ПК.

Весь цифровий матеріал досліджень піддавали статистичній обробці (Plokhynskyi, 1969) з використанням стандартного програмного забезпечення "StatPlus 2008". Відмінності між середніми показниками бджіл дослідної групи до контрольної вважали статистично достовірними при $\mathrm{P}<0,05-* ; \mathrm{P}<0,01-* *$; $\mathrm{P}<0,001-* * *$.

\section{Результати та їх обговорення}

Основним джерелом Мангану для медоносних бджіл є квітковий пилок. У залежності від виду пилку вміст Мангану коливається від 0,65 мг $/ 100$ г у кульбаби, до 4,51 мг/100 г у озимого ріпаку. Збираючи пилок та змішуючи 3 медом і секретами слинних залоз бджоли складають його в стільники. 3 нього утворюється новий продукт - перга. Кількість Мангану в перзі $\epsilon$ величиною, яка може характеризувати середній вміст елементів, що будуть поступати в організм 
бджоли, оскільки бджоли складають в чарунки обніжжя різного виду. Тому, в перзі кількість Мангану є меншою порівняно з пилком у 3-4 рази. Поряд з цим, зменшення Мангану в перзі зумовлено низьким вмістом його в нектарі. Однак деяка частина мікроелементу поступає в організм бджоли з нектаром. У залежності від ботанічного походження в меді його мінеральний вміст може бути різним (Plokhynskyi, 1969). Згідно наших досліджень в умовах Львівської області у золотарниковому меді вміст Мангану становить 0,19 мг/100 г. Очевидно споживаючи виключно мед в організм медоносної бджоли не надходить необхідна кількість мікроелементів, у тому числі і Мангану. Тому в практичному бджільництві велику увагу приділяють перговому забезпеченні бджолиної сім’ї. Використання замінників перги при годівлі бджіл призводить до того, що організм поступає недостатня кількість мінеральниих речовин. Зокрема, при використанні, у якості білкової підгодівлі, бджолам замість перги вводять у раціон борошно сої яке за вмістом Мангану у 2,5 разів є меншим.

Споживаючи біля 25 кг бджолиного обніжжя в рік у організм медоносної бджоли поступає достатня кількість поживних речовин в основному через його поліфлорність. Недостатня кількість одного з елементів у пилку компенсовується споживанням пилку 3 інших рослин. Однак, для вивчення факторів, які можуть впливати на інтенсивність метаболізму в організмі бджоли потрібно знати яка кількість нутрієнів поступає в організм. Тому ми задались метою вивчити мінеральний склад бджолиного обніжжя різного ботанічного походження.

\section{Таблиця 1}

Вміст Мангану в обніжжі Стрийського району Львівської області (M \pm м, $\mathrm{n}=5$, мг/100 г обніжжя)

\begin{tabular}{lllll}
\hline \multicolumn{5}{c}{ Вид пилку } \\
\hline кульбаба & ріпак о3. & клен & гречка & конюшина \\
\hline
\end{tabular}

$4,51 \pm 0,07 \quad 4,50 \pm 0,21 * 3,75 \pm 0,18 \quad 2,32 \pm 0,23 * 1,87 \pm 0,11 * * *$

Примітка: вірогідна різниця між кульбабовим і іншими видами пилку (*- $\mathrm{P}<0,05 ; * *-\mathrm{P}<0,01 ; * * *-\mathrm{P}<0,001)$

3 даних таблиці 1 видно, що найбільша кількість даного мікроелементу міститься в зразках з кульбаби та ріпаку озимого і становить 4,5 мг/100 г обніжжя. У конюшиновому обніжжі зафіксована найменша кількість Мангану 1,87 мг/100 г. Звертає на себе увагу незначний вміст Мангану у бджолиному обніжжі 3 гречки 2,32 мг/100 г.

Кількість Мангану в бджолиному обніжжі у великій мірі залежить також від району його збору. Аналізуючи геохімічні особливості мінерального складу пилку деяких районів Львівської області ми бачимо, що кількість Мангану в бджолиному обніжжі не є величиною стабільною (табл. 2).

Досліджено бджолине обніжжя 3 шести пасік Львівщини. Усі бджолині сім'ї розміщені на ділянках які не межують 3 дієвими підприємствами і розташовані в лісових масивах. Бджолине обніжжя яке було відібране у травні, у період цвітіння кульбаби, дає нам уяву про вміст мінеральних речовин. 3 даних таблиці випливає, що максимальна кількість Мангану виявлено в Камянко-Бузькому обніжжі. 3 пасіки Дрогобицького району бджолине обніжжя відрізнялось найменшим вмістом Мангану.

\section{Таблиця 2}

Вміст Мангану в кульбабовому обніжжі деяких районів Львівської області ( $\mathrm{M} \pm \mathrm{M}, \mathrm{n}=5, \mathrm{Mг} / 100$ г обніжжя)

Назва району

Кам-
Бузький Миколаївськ Турківський Стрийський Дрогобицьк $5,91 \pm 0,18 \quad 5,26 \pm 0,11 \quad 4,89 \pm 0,21 \quad 4,50 \pm 0,05 \quad 3,37 \pm 0,21$

Можливо міграція Мікроелементу залежить від його наявності в грунті. При цьому, існують інші фактори, які впливають на засвоєння мікроелементів рослинами.

Згідно даних наших досліджень у в організмі медоносних бджіл виявлені зміни кількості Мангану на деяких періоду онтогенезу (рис. 1). Постнатальний період ми почали з вивчення вмісту Мангану у личинок 3 добового віку. У цей період личинка споживаючи виключно маточне молочко і містить 7,29 мг /100 г цього елементу. На рисунку чітко виражено зниження вмісту Мангану в тілі 6-ти добових личинок порівняно $з$ 3-ох добовими. Так, кількість Мангану зменшується на 19,0 \%. Таке зниження 3 віком пов'язане 3 характером живлення адже у цей період личинкам старшого віку до корму додають мед і пергу, що очевидно збіднює раціон за вмістом Мангану.

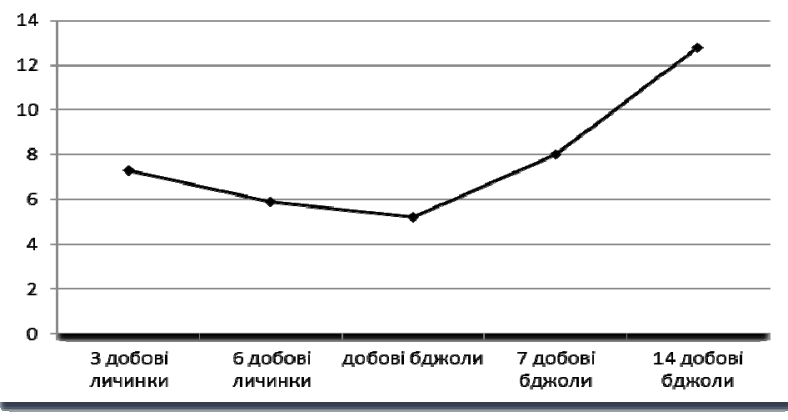

Рис. 1. Динаміка Мангану в організмі медоносних бджіл на деяких періодах онтогенезу, (мг/100 г)

У тілі бджіл, які вийшли з комірок вміст Мангану становить 5,18 мг/100 г. Після виходу 3 комірок, бджоли починають споживати велику кількість перги для нарощування жирового тіла та нормального функціонування залоз і у зв'язку з цим у тілі 7 добових бджіл відбувається нагромадження Мангану. Максимальну кількість у імагінальний період виявлено у 14добових бджіл. Його кількість становила 12,83 мг/100 г. Бджоли саме цього віку вважаються найбільш фізіологічно адаптованими до побудови гнізда і початку льотної діяльності (Polishchuk, 2001).

Наступний етап досліджень полягав у визначенні вмісту Мангану за впливу сезону року. Актуальність досліджень полягає у тому, що різні відділи тіла мають різну анатомічну будову, а отже, і функціональне 
призначення. Зменшення Мангану в організмі добових бджіл спостерігається з літа до зими (табл. 3).

Таблиця 3

Сезонні зміни вмісту Мангану в організмі медоносних бджіл $(\mathrm{M} \pm \mathrm{m}, \mathrm{n}=5, \mathrm{M \Gamma} / 100$ г)

\begin{tabular}{ccc}
\hline Частина тіла & Літо & Зима \\
\hline Голова & $1,77 \pm 0,01$ & $16,18 \pm 1,31$ \\
Груди & $2,96 \pm 0,06$ & $21,11 \pm 0,11$ \\
Черевце & $53,1 \pm 0,51$ & $26,49 \pm 0,51$ \\
Разом & $57,83 \pm 0,41$ & $63,78 \pm 0,32$ \\
\hline
\end{tabular}

Влітку кількість Мангану в організмі бджіл складає у голові $-1,77$ мг/100 г, грудях $-2,96$ мг/100 г, черевці - 53,1 мг/100 г. Максимальна кількість у черевці, очевидно повязана 3 тим, що у цей період воскові залози перебувають на піку розвитку. У місяці грудні ми проаналізували кількість Мангану в організмі комах, які почали зимівлю. 3 таблиці 3 видно, що загалом його кількість збільшується особливо в голові та грудному відділі. Практично вдвічі зменшується вміст Мангану в черевці.

Згідно проведених досліджень встановлено, що основна кількість Мангану в організмі медоносних бджіл міститься в кутикулі - зовнішньому скелеті, що покриває ії тіло і хітинових утвореннях, що складають внутрішній скелет. Його кількість становить в середньому 1,78 мг/100 г. У тілі бджоли вміст Мангану коливається в широких межах. Ці коливання залежать від таких факторів як: вік, сезон, геокліматичні умови, рівень годівлі та ін. Значна кількість Мангану виділяється з секретом харчетравних залоз робочих бджіл маточним молочком у кількості 1,55 мг на 100 г. Поряд 3 цим, Манган необхідний для утворення секрету воскових залоз та апітоксину. Манган також входить до складу білка мязів міоглобіну. У м'язових волокнах депонується 1,8 мг/100 г Мангану. Вивільнення Мангану з організму бджоли проходить через видільну систему. У калі бджіл при нормальному режимі годівлі спостерігається значне нагромадження Мангану, що вказує на наявність великої кількості ферментів пероксидного окислення. Під кінець зими екскременти містять 44,32 мг/100 г Мангану. У цукровому сиропі, переробленому і складеному в стільниках, порівняно 3 медом відсутні десятки мікроелементів в тому числі і Манган. Тому, додавання певних доз деяких мікроелементів, зокрема Мангану до корму, балансують раціон за їх вмістом. Одна з фізіологічних функцій Мангану в організмі бджоли полягає в тому, що вона входить в склад багатьох ферментів, в тому числі і ферментів, які запобігають шкідливому впливу на організм, який може виникнути при заповненні кишечнику каловими масами, від зігнивання і бродіння (Lebedev \& Bilash, 1991). Раніше нашими дослідженнями було встановлено, що при додаванні Мангану до штучних замінників перги активність ферменту каталази зростала на 22,5 \%.

У наукові літературі недостатньо даних щодо розподілу мінеральних речовин відносно статі. Визначення вмісту Мангану в різних відділах медоносних бджіл і трутнів вказує на особливості депонування.
Статеві відмінності щодо вмісту Мангану у медоносних бджіл мають різкі коливання, особливо в деяких відділах тіла комах. Так, у робочих бджіл вміст Мангану коливається в межах 57,83 мг/100 г. Особливо багато його депонується в черевці 53,1 мг/100 г. Можливо це пов'язано 3 тим, що анатомічно черевце робочої бджоли містить тканини, які функціонально не притаманні трутням. На нашу думку Манган у більшій мірі потрібна для синтезу секрету воскових залоз та для ділення адипоцитів жирового тіла. Статеві відмінності щодо вмісту Мангану в голові не виявлені (табл. 4).

\section{Таблиця 4}

Статеві відмінності вмісту Мангану в організмі медоносних бджіл $(\mathrm{M} \pm \mathrm{m}, \mathrm{n}=5, \mathrm{Mг} / 100$ г)

\begin{tabular}{crr}
\hline Частина тіла & Робочі бджоли & \multicolumn{1}{c}{ Трутні } \\
\hline Голова & $1,77 \pm 0,01$ & $1,89 \pm 0,06$ \\
Груди & $2,96 \pm 0,06$ & $2,23 \pm 0,11$ \\
Черевце & $53,1 \pm 0,51$ & $24,01 \pm 0,73$ \\
Разом & $57,83 \pm 0,41$ & $28,13 \pm 0,21$ \\
\hline
\end{tabular}

Грудний відділ робочих бджіл і трутнів з морфологічної точки зору не відрізняється. Однак, кількість Мангану в грудному відділі неодинакова. Так у робочих бджіл вміст Мангану більший на 24,66 \% порівнянно 3 грудним відділом трутнів. Дослідження у цьому напрямку мають свої перспективи з огляду на те, що не до кінця зрозуміло у яких саме тканинах спостерігається таке депонування. Поряд з цим залишається незрозумілим чому таке нагромадження виявлено саме у черевці адже характер живлення робочих особин i трутнів однаковий. Припускаємо, що вміст Мангану впиває на процеси синтезу деяких секретів, зокрема воску та апітоксину.

\section{Висновки}

Таким чином, результати наших досліджень свідчать про те, що вміст Мангану у різних тканинах і на різних етапах онтогенезу медоносної бджоли відображає стан мінерального живлення. Склад монофлорного обніжжя за вмістом Мангану не є постійним. Мінеральний склад організму бджіл, в основному залежить від кількості мінеральних неорганічних сполук спожитих з кормом. Динаміка нагромадження Мангану спостерігається не тільки залежно від статі, віку, сезону року але і від фізіологічних особливостей бджолиних сімей.

\section{References}

Drujbiak, A., Mironovich, A., Kovalska, L., \& Kovalskyi, Y. (2017). Pollen analysis included rectum of honey bees. Scientific Messenger of LNU of Veterinary Medicine and Biotechnologies. Series: Agricultural Sciences, 19(79), 135-139. URL: https://nvlvet.com.ua/index.php/ agriculture/article/view/2795.

Kerek, S., Kovalskyi, Y., \& Husar, P. (2017). Description features exterior carpathian bee different origins. Scientific Messenger of LNU of Veterinary Medicine 
and Biotechnologies. Series: Agricultural Sciences, 19(74), 239-242. URL: https://nvlvet.com.ua/ index.php/agriculture/article/view/2336.

Kovalchuk, I., Dvylyuk, I., Lecyk, Y., Dvylyuk, I., \& Gutyj, B. (2019). Physiological relationship between content of certain microelements in the tissues of different anatomic sections of the organism of honey bees exposed to citrates of argentum and cuprum. Regulatory Mechanisms in Biosystems, 10(2), 177 181. doi: 10.15421/021926.

Kovalskyi, Yu. V. (2005). Fizioloho-biokhimichni ta produktyvni pokaznyky karpatskykh bdzhil za dii alimentarnykh chynnykiv. Avtoref. kand. s.-h nauk. 03.00.04. Lviv (in Ukrainian).

Kovalskyi, Yu. V., \& Kyryliv, Ya. I. (2003). Mineralnyi sklad bdzholynoho obnizhzhia. Naukovyi visnyk LDAVM, 4(4), 57-61 (in Ukrainian).

Kovalskyi, Yu., Gucol, A., Gutyj, B., Sobolev, O., Kovalska, L., \& Mironovych, A. (2018). Features of his- tolism and hystogenesis in the vital temperature range in the organism of honey bee (Apis mellifera L.) in the postembrional period. Ukrainian Journal of Ecology, 8(2), 301-307. doi: 10.15421/2018_342.

Kuprijanova, L. A., \& Al'oshina, L. A. (1978). Pyl'ca i spory rastenij flory evropejskoj chasti SSSR. M. (in Russian).

Lebedev, V. I., \& Bilash, N. G. (1991). Biologija medonosnoj pchely. Moskva VO "Agopromizdat" (in Russian).

Plokhynskyi, N. A. (1969). Rukovodstvo po byometryy dlia zootekhnykov. M.: Kolos (in Ukrainian).

Polishchuk, V. P. (2001). Bdzhilnytstvo. Lviv, Ukrainskyi pasichnyk (in Ukrainian).

Voronina, L. M., Desenko, V. F., Madiievska, N. M. (2000). Biolohichna khimiia. Kh. (in Ukrainian).

Zhulai, V. Ie. (1989). Mineralnyi sklad riznykh sortiv medu. Pasika, 9, 22 (in Ukrainian). 